\title{
Biosemiotics and Body Signifier Theory: a way to understand High Dilutions
}

\author{
Leoni Villano Bonamin
}

Universidade Paulista - UNIP, Brazil

\begin{abstract}
Since the 80's Madeleine Bastide and Agnès Lagache have worked on the idea of the Body Signifier Theory, in which the living systems could be defined as "sensible" systems not only able to self-organize, but also to receive and process non-molecular information according to the Pierce semiotic triad: matrix, receiver and carrier. These ideas were built along 20 years of experimental observations, whose results presented some kind of stereotyped pattern that emerged from cells or animals exposed to high dilutions, according to the similia principle. Curiously, at the same time, classical scientific communities have developed the concept of biosemiotics after the observation that living systems are semiotics entities able to deal with codes and meanings, even in molecule-driven processes. Not only the genetic code, but all regulatory functions in living systems represent coding processes. The development of methodologies to identify and understand these codes and its outputs is the aim of biosemiotic science. Putting both concepts together (body signifiers and biosemiotics), it is possible to recognize strong similarities between their approaches and methodology, allowing logical connections between non-molecular signals and changes in cell interactions patterns. Thus, the general concept of biosemiotic could be a theoretical platform on which the construction of a solid phenomenological description of high dilutions effects could be done.
\end{abstract}

Keywords: signifier body theory, biosemiotics, homeopathy, high dilutions.

\section{(c) BY-NC-ND Licensed to GIRI}

Support: author declares that this study received no funding

Conflict of interest: author declares there is no conflict of interest

Correspondence author: Leoni Villano Bonamin, leonibonamin@gmail.com.

How to cite this article: Bonamin LV. Biosemiotics and body signifier theory: a way to understand high dilutions. Int $\mathrm{J}$ High Dilution Res [online] 2011 [cited YYYY Month dd];10(35):66-66. Proceedings of the XXIV GIRI Symposium;2010 Nov 05; Monte Carlo (Monaco). GIRI; 2010. Available from: http://www.feg.unesp.br/ ojs/index.php/ijhdr/article/view/448/461 